\title{
Values Education as a Social Instrument for Reducing Corruption, Poverty and Inequality
}

\author{
Victor J. Pitsoe \\ Department of Educational Leadership and Management, \\ College of Education, University of South Africa \\ Email address: Pitsovi@unisa.ac.za
}

\section{Doi:10.5901/mjss.2013.v4n13p745}

\begin{abstract}
Corruption has been the topic of many debates and much literature. Yet it remains a global challenge with far- reaching implications: it promotes and sustains a vicious cycle of poverty and leads to poor schooling environments. The underlying assumption in this article is that teaching values education is not only a way to escape poverty, but it is a way to fight it. Therefore, this article offers an account of the epistemology of theory and practice of corruption, poverty and inequality reduction. Drawing on the critical pedagogy framework and systems theory, this article (1) conceptualises values education in the South African context; (2) argues for schools as institutions for social and cultural reproduction; (3) explores discourses on corruption; (4) reflects on teaching values education as a means of fighting and reducing corruption and inequality; and (5) sketches corruption as an obstacle to the achievement of the Millennium Development Goals (MDGs) and Education For All (EFA).
\end{abstract}

Keywords: values education, corruption, poverty, inequality, social reproduction, MDGs, EFA

\section{Introduction}

Education, as a social instrument, is never an autonomous process, separate and apart from the society it serves. Most importantly, it finds its central purpose - its guiding principles - in the particular social order in which it develops and functions. Hence, teaching values education is critical for the attainment of the Millennium Development Goals (MDGs) and Education For All (EFA) worldwide, but even more specifically in the context of South Africa. Teaching values education is also essential for the construction of democratic and values-driven societies and, most importantly, for building a strong moral foundation. For democracy to flourish there must be a values-driven and active citizenry that takes personal responsibility for social activities, including government. Yet, repeated infringements (high levels corruption and violation of basic human rights) of essential democratic values and foundations have posed significant challenges to the attainment of the MDGs and EFA. Moreover, corruption, poverty and inequality should not be seen in isolation, since they are so closely related.

In recent years, as in the past, there have been a significant number of debates and articles written about corruption (bribery, fraud, kickbacks and other illicit payments). As Uslaner (2007) puts it, corruption flouts rules of fairness and gives some people advantages that others don't have. In essence, it undermines the trust between the state and citizens, derails service delivery and provides a fertile breeding ground for poverty. Nonetheless, corruption - as a social ill - remains a global challenge and has far-reaching implications: it promotes and sustains a vicious cycle of poverty and leads to poor schooling environments. In addition, it is a barrier to the implementation of national, regional and global policies. Hence, preventing and deterring corruption requires the introduction of teaching values (ethics) education in schools as a preventive measure. One of the puzzles yet unresolved by scholars in the South African context is how teaching values education can be used as a strategy for poverty and inequality reduction. This article hold that teaching values education is a political act that can serve to challenge, enforce or reconstruct societal norms and values. Furthermore, it sees schools as centres of community development and change agents, which can transform students' lives and the communities they serve. Values education, as an instrument of social change, promotes democracy, accountability, peace and stability. Among others, teaching values education helps to reduce poverty and promote equity and social justice - it thus plays a central role in preventing social exclusion.

With this background in mind, the contemporary corruption, poverty and inequality reduction discourse has one fundamental flaw: it fails to recognise the interrelationship between these concepts and lacks the attributes of a systems theory. The discourse on corruption, poverty and inequality reduction in the case of South Africa suffers from the same 
weakness. Yet within this context, teaching values education is critical for the worldwide attainment of the Millennium Development Goals (MDGs) and Education For All (EFA). This article is based on the assumption that teaching values education is not only a way to escape poverty, but it is a way to fight it. It offers an account of the epistemology of theory and practice of corruption, poverty and inequality reduction.

Notwithstanding the challenges of financing and the affordability of education for the poor, the teaching of values education has the prospects of improving/correcting dysfunctional schooling in South Africa, which accounts for much of the absenteeism, bullying, violence and high dropout rate in schools. The latter are precursors of delinquent and violent behaviour and are closely related to poverty. Drawing on the critical pedagogy framework and systems theory, this article (1) conceptualises values education in the South African context; (2) argues or schools as institutions for social and cultural reproduction; (3) explores discourses on corruption; (4) reflects on teaching values education as a means to fight and reduce corruption and inequality; and (5) sketches corruption as an obstacle to the achievement of the Millennium Development Goals (MDGs) and Education For All (EFA).

\section{Conceptualising values education in the South African context}

It would be apposite to begin this section by exploring the origin of the concept "values education". The origin of the word in Latin (valere) and old French (valior) refers to that which is worth striving for. A value is an enduring belief that a specific mode of conduct or end-state of existence is personally or socially preferable to an opposite or converse mode of conduct or end-state of existence (Niewenhuis, 2007:9). Values clarification seeks to help students identify their own beliefs, and values education may help students to identify or choose from core values such as tolerance, love, fairness, freedom, unity, responsibility, respect for life and the truth (Kidder, 2009:85). Education is never value-free and neutral. Values education, in its generic sense, embraces both ethical and non-ethical values (Bagnall, 2007:72). It is as old as education itself and is known internationally by a number of names, including moral education, character education, ethics education, citizenship education, religious education and democratic education (Nieuwenhuis, 2007; Aspin, 2007; Pendlebury \& Enslin, 2007).

Each variant has a slightly different meaning, pointing to one or other distinctive emphasis. In spite of these different meanings, values education still plays a vital role in social change. It shapes morals, mentality and culture in agreement with the economic class. Therefore, if South African schools and educators are to follow this route, they must be knowledgeable about how to prepare students to accept social change and make appropriate and positive social changes for the good of society. This article views schools as nascent communities where teachers, as social reproduction agents, can influence social change and can use behavioural (or mis-behavioral) opportunities to help in rebuilding a sense of community in the adult world, which students often emulate.

Social change is a concept that is riddled with ambiguities and contradictions. It is not a homogeneous process and has both positive and negative dimensions. Several ideas of social change have been developed in various cultures and historical periods. However, aspects of societal change may be summarised under three main headings: economic, political and cultural. Social change refers to any significant alteration over time in behaviour patterns and cultural values and norms. For some scholars, social change is the alteration of mechanisms within the social structure, characterised by changes in cultural symbols, rules of behaviour, social organisations or value systems. In its broadest sense, social change is any change in social relations. Viewed this way, it is an ever-present phenomenon in any society. A distinction is sometimes made, then, between processes of change within the social structure, which serve in part to maintain the structure, and processes that modify the structure (societal change).

Social change is a tune for the postmodern age. Priestley (2011:1) observes that education systems worldwide mirror this overall trend, with the last 15 years being characterised by what Levin has described as an epidemic of change. Based on this observation, the burning questions are: How can teaching values in education as a political act contribute towards social change? and How can schools influence social change? Education is a social instrument of great importance, and it is never an autonomous process, separate and apart from the society it serves (Edwards, 1951:39). It always develops within a particular social context and it is anchored in the civilisation of which it is a part; in a very real sense, it is the child of historic circumstance. Education always finds its central purpose, its guiding principles, in the particular social order in which it develops and functions.

The role of education as an agent or instrument of social change and social development is widely recognised today (Johnson et al, 2008:329). Social change may take place when humans need change, for instance when the existing social system or network of social institutions fails to meet existing human needs and when new materials suggest better ways of meeting those needs. The literature reveals that social change takes place in response to many types of changes that take place in the social and non-social environments. For this reason, teaching values education 
has the potential to initiate social changes by bringing about a change in the outlook and attitude of students. It can change the pattern of social relationships and may thereby cause social changes.

In line with this, South Africa's transition from a racist apartheid society to a fully democratic nation calls for the teaching of a values education that is rights-based and underpinned by Dewey's principles. Dewey held that schools are agents for social change. As a progressivist, he argued that if teachers make efforts to find answers about the idea(s) of democracy then we will be better able to understand how schools can contribute to social change. Dewey held that overdependence on subject knowledge and methods was not in the best interests of education. Instead, he promoted the cultivation of a mindset on the part of teachers that is both self-reflective and directed towards instilling reflectivity, inquiry and a capacity for moral judiciousness on the part of students (Dewey, 1964;1946). This idea was supported by Jurgen Habermas, whose theory of knowing provides a particularly powerful tool for analysing the capacity of values education to change people's beliefs and behaviours to make the kind of difference that would seem to be its promise a significant/desirable difference. This change is described by Habermas as "praxis", a practical or communicative action designed to right the wrongs in one's environment.

In view of the above, values education is timely in the South African context, where a process is under way to review the national curriculum in state schools and higher education continues to evolve. Education is used to inculcate values and practices where the society is ensuring that continuity is established with the culturally laden past while society perpetuates the cultural values of the past. Hence, schools should be viewed as embryonic communities, where teachers can use behavioural (or misbehavioral) opportunities instances of good or bad behaviour to help rebuild a sense of community in the adult world, which children often emulate. From a democratic perspective, parents and other community members and institutions should see themselves as partners, rather than as outsiders. Thus, education constitutes an essential social process that will inevitably attract the attention of social, religious, economic and political interest groups (Nieuwenhuis, 2007:7). In addition, these groups know that education has the potential to shape the future society, and therefore they are bound to view schools as institutions that can promote their goals.

\section{Schools as institutions for social and cultural reproduction}

To deny schools the right/chance to inculcate democratic values and practices where the society is ensuring that continuity is established with the culturally laden past while society perpetuates the cultural values of the past is to undermine the very nature of education and science. It also suggests that the curriculum is free from ideological tension, which is questionable. This article sees the rejection to this as tantamount to the rejection of liberation, decolonisation and democratisation. Sadly, from a social reproduction theory perspective, schools are not institutions of equal opportunity, but mechanisms for perpetuating social inequalities. The school, according to Bourdieu and Passeron (1990), has both internal and external functions. The internal function of the school is said to be inculcating values and the external function is to reproduce the legitimate culture.

Cultural reproduction is the transmission of existing cultural values and norms from generation to generation. Cultural reproduction refers to the mechanisms by which continuity of cultural experience is sustained over time. Cultural reproduction often results in social reproduction, or the process of transferring aspects of society (such as class) from generation to generation. Recent empirical evidence has shown that theories of social reproduction focus mainly on schools. One of Bourdieu's best-known theses is of the school as a conservative force. This has, however, given rise to a misconception, for Bourdieu does not, in fact, argue that the school is merely a passive instrument for the reproduction of family-acquired habitus, which "objectively" certifies the dominant cultural code of society (Nash, 1990:435).

Bourdieu's investigation of the connection between the school and systems of thought situates the school, in nontraditional societies, as the central generative site of the distinctive habitus of the culture. Hence Bourdieu (1990; 1988; 1984) notes that it may be assumed that every individual can attribute a set of basic, deeply interiorised master patterns to the type of schooling he/she has received. As a result, in this theory, schooling has its own power to shape consciousness, over and above the power of the family, and it is clear that the role of the school is acknowledged as active and not merely passive in its "legitimation" of family-acquired habitus (ibid).

Concern with the processes whereby societies and cultures perpetuate themselves has an ancient pedigree, traceable to Aristotle's analysis of the domestic economy in political orders (Collins, 2009:34). However, in recent years there has been a growing body of literature suggesting that schools are institutions for social and cultural reproduction. The concept of cultural reproduction was first developed by cultural theorist Pierre Bourdieu in the early 1970s. Social reproduction theory offers a paradigm of class analysis argued to be capable of explaining persistent inequalities in educational stratification, despite state efforts at educational expansion cross-nationally (Tzanakis, 2011:76). 
According to Bourdieu, children from middle-class families are advantaged in gaining educational credentials owing to their possession of cultural capital. In this article, I acknowledge that Bourdieu may be criticised for not being precise enough about exactly which of the resources associated with the higher-class home constitute cultural capital, and how this resource is converted into educational credentials. Capital, in Bourdieu's theory, can be defined as a resource that can have monetary or non-monetary forms, as well as tangible or intangible forms. For Tzanakis (2011:76), cultural capital is assumed to be one of the central family-based endowments whose social class value affects offspring's intergenerational educational probabilities unequally. It assumes central importance in the above process of social reproduction because inequalities in cultural capital reflect inequalities in social class.

Society has institutions through which it reproduces itself: the family, the economy, the government, religion and education. All institutions are meant to socialise their members. From a social reproduction theory stance, educational institutions follow the directions of the dominant group to maintain the status quo of the society; in other words, lower-, middle- and upper-class children become lower-, middle- and upper-class adults respectively. This is a cyclic process as the dominant group entrenches the values and aims favouring itself in educational institutions. The dominant group also promotes the myth - through other institutions such as the government and the economy - that education is for all and provides a means of achieving wealth and status. In a nutshell, the social reproduction framework sees the true function of schools as preparing students to assume a job in the same socioeconomic status as the dominant social classes.

Education always finds its central purpose, its guiding principles, in the particular social order in which it develops and functions (Edwards, 1951:394). Stambach (2012:324) notes that education is a language and repertoire of social practices through which families, students and educators themselves remake their own class-consciousness, largely through their complicit participation in the mechanics of the system. From a critical pedagogical perspective, education is a key site of cultural production and social reproduction. It is not a pre-given container or universal and unchanging category of social relations and life-worlds, but a complex terrain and outcome of discursive, material and institutionalised struggles over the role of education in the social contract. Within a social reproduction framework, education provides the necessary skills for production, the necessary graded ideologies for the social division of labour, and the necessary milieu for the actual formation of subjectivities through the celebrated "imaginary relationships of individuals to their real conditions of their existence" (Willis, 1981:51). Snook (2007:80) notes that schools in democratic societies have been traditionally expected to reinforce the basic values of these societies to initiate young people into traditions of critical thought.

In summary, schools may be regarded as potential institutions of change - for good or for ill - in any society. They play a pivotal role in influencing social, moral and ethical change. Morality - in its strictest sense - is a universal feature of human culture. Any society without a modicum of morality and ethics must collapse. Bourdieu's theory about the role of schools and teachers in the transmission of intergenerational inequalities rests on a number of assumptions about the teacher population and the school context. The role of the school is to promote arbitrary cultural and democratic values via teachers.

\section{Discourses on corruption}

To start with, etymologically, the word "corruption" comes from the Latin word "corrumpo", which literally means to decompose, or to disintegrate, to lose value, to become putrid and useless (Ochulor \& Bassey, 2010:469). In other words, corruption simply means to lose purity or integrity. Discourses on corruption are very much part of public debates and everyday conversations in many parts of the world, and are broadly perceived. Quite often, the developed world is implicated in corruption in the developing world, both as the source of the bribes and as the depository for corruptly acquired funds. Simply stated, the developing countries provide fertile grounds for corruption perpetrated by the developed countries. As explained by Heidenheimer et al (1989:6), corruption is a transaction between private and public sector actors through which collective goods are illegitimately converted into private-regarding payoffs.

Corruption covers fraud (theft through misrepresentation), embezzlement (misappropriation of corporate or public funds) and bribery (payments made in order to gain an advantage or to avoid a disadvantage). Although it is broadly perceived, a large body of research indicates that corruption takes many forms. The first is incidental corruption: this is small-scale; it involves junior public officials, such as police officers or customs officers; it produces profound public alienation; it has little macro-economic cost, but it is often hard to curb. Secondly, there is systematic corruption: this is corruption that affects, for example, a whole government department or parastatal. It can have a substantial effect on government revenues; it may divert trade and/or development; and it can be dealt with only through sustained reform. Thirdly, there is systemic corruption, that is, kleptocracy or government by theft: in this situation, honesty becomes irrational and there is a huge developmental impact. 
Corruption is not just a problem for the developing world; it is a global problem - it can be seen everywhere and can be either need-based or greed-based. However, corruption has also attracted much attention from other social sciences, in particular from political scientists and, more recently, from sociologists and anthropologists (Andvig et al, 2000). For this reason, to understand corruption, the political factors cannot be ignored. As Mauro (1997) puts it, corruption has been around for a very long time and will be around in the future, unless governments can figure out effective ways to combat it.

Corruption is a very complex and multifaceted phenomenon with multiple causes and effects, as it takes on various forms and functions in different contexts (Andvig et al, 2000). In addition, the phenomenon of corruption ranges from the single act of a payment contradicted by law to an endemic malfunction of a political and economic system. In spite of its complex nature, corruption remains a reality even in the world's most developed countries. It can exist at all levels, from national to municipal government. It is like a cancer in public life, but not one that spreads overnight; rather, it is an insidious disease that worsens over time. In public life, corruption is found in politics, state governments, central governments, business, industry, and so on. It is like a chronic condition: it cannot be eliminated entirely, but only controlled. Therefore, while it may not be possible to root out corruption completely at all levels, it is possible to contain it within tolerable limits.

Research suggests that political corruption in democratic settings comes in various visages, each one more grotesque than the other. The most common of these are patronage, bribery, graft, extortion, influence padding, embezzlement and nepotism. However, what constitutes corruption differs, depending on the country and its jurisdiction. For example, certain political funding practices that are legal in one country may be illegal in others (Transparency Ethiopia 2012). For Andvig et al (2000), corruption also exists within and between private businesses and within nongovernmental organisations, without any state agency or state official being involved. There is corruption in terms of bribing, swindling and mafia-methods in businesses, and there are disloyal employees in private firms, non-governmental organisations and associations. These authors argue that corruption also exists as a moral and cultural problem in society, among individuals in their personal dealings. Accepted and expected practices of gift-giving, tipping and patronage exist in most societies, even when such customs may be illegal. Generally, such practices impose hidden costs on public services and/or confuse the distinction between public and private (Andvig et al, 2000).

It has been found that there is a casual relationship between low salaries and corruption. For example, researchers Rijckeghem and Weder (1997) explored the extent to which the level of public sector salaries is linked with the level of corruption. Their basic argument is that low salaries force public officials to supplement their income by taking bribes, while high salaries imply higher alternative costs if detected for fraudulent behaviour. In a sample of 28 countries, Rijckeghem and Weder found a significant negative influence of public sector salaries relative to wages in the manufacturing sector in terms of corruption: They concluded that if public sector wages were doubled, the corruption index of a country would improve in the order of 2 points on the corruption index (CPI) of Transparency International. However, there may be a problem of causality in their analysis, since corrupt (and poor) countries tend to have poor budgetary performance and, therefore, may keep civil service wages low as a consequence.

Lastly, this article perceives mixing gift-giving and bribes as a sure recipe for corruption. For example, if public employees are underpaid and/or unpaid, they will seek to supplement their income by exploiting any 'insider' status they may have, seeking to 'sell' ostensibly free public services. Unpaid teachers, for example, may seek bribes from parents who want to place their children in the school. On the other hand, there is a strong correlation between corruption and economic development. Empirical research (Andvig et al, 2000) based on various corruption indexes shows a correlation between certain forms of government regulations, poor public institutions, poverty and inequality. Despite its complexity, the consequences of corruption have far-reaching implications. Corruption is a treacherous phenomenon, since it violates the basic tenets of democratic governance. Among other things, corruption infringes the fundamental human rights to fair treatment, unbiased decision making and secure civil and political status. As a result of corruption, the public services on which the poor depend are starved of funds, foreign investors are driven away, and environmental protection measures are flouted. It is often difficult to assess whether corruption causes other variables or is itself the consequence of certain characteristics.

\section{Teaching values education as a means of fighting and reducing corruption and inequality}

It is perhaps appropriate and fitting to start this section by asking: Is corruption lower in democratic countries and those with a free press and strong civil associations? In answering that question, we have to explore a number of empirical studies regarding the possible correlation between corruption and democracy (e.g. Harris-White \& White, 1996; Paldam, 1999; Goldsmith, 1999; Treisman, 2000). For instance, Paldam (as cited by Andvig et al, 2000) finds that democracy 
seems to decrease corruption, but both variables interact strongly with the level of transition. Therefore, he suggests that the independent effect of democracy on the level of corruption is dubious. Notwithstanding a commendable volume of empirical studies that suggest a possible correlation between democracy and corruption, this article acknowledges critics' contention that democracy is the worst form of government, except all the others that have been tried. However, it departs on a constricted political notion of democracy, which includes the following attributes and values: (1) the accountability of rulers through regularised multiparty, free and competitive elections; (2) political institutions and policies that reflect societal values as established and changed via formal electoral and legislative mechanisms; (3) the freedom to associate and organise politically; and (4) the rule of law.

In spite of the violation of basic individual rights and authoritarianism that characterised the apartheid regime, this article argues that democratic values - in all of their historical and contemporary forms - have played a pivotal role in shaping conceptions of the current public education system. The second and, perhaps, more profound reason for the clamor for democracy is the classic contributors to modern political thought and commentary, as well as those who framed modern arguments, have dealt specifically with the educational necessities of establishing and maintaining a democratic polity. They have generally reflected on the tensions between the socialisation of a democratic nation's subjects (i.e. as acculturated, law-abiding members) and the education of its citizens (i.e. critically thinking, active participants).

Values education is concerned with the promotion of values - moral, social, political, aesthetic - as vital elements in progammes of education for future life (Aspin, 2007:30). Like political institutions, education is hopefully moving towards a broader democracy in which each person is free to develop his/her interests and abilities (Stewart, 1975:159). Herein, he (Stewart) contends rests the enigma with which teachers are now faced: maintaining order that is consistent with democratic values. Democracy is an intelligent moral and ethical action that is practised in a community that strives to maximise human development, ensure and diffuse freedom, and create positive peace built on the presence of goodwill, rather than on the absence of fighting (Stewart, 1975:160). Of primary importance is how people live and practice the constitutional values. I find it rather senseless to talk to students about democracy, tolerance, equality and similar values if the teachers and public officials, including politicians, are not putting these values into practice. If these ones were to show respect to each other and to the students, for example, it could help the students gradually to learn the true meaning of respect. A teacher cannot just talk about democracy; he/she must be democratic in all his/her actions to help the students to become democratic too (Stewart, 1975:160).

According to one line of thought, moral development occurs through a sequence of universal stages. Although it has been commonly assumed that ethical practice, moral values and beliefs are acquired through some process of cultural transmission, or of identification with the beliefs and values of parents and members of adult society, the research of Kohlberg and his associates indicate that children pass through an invariable sequence of stages of reasoning about values and beliefs, and the mode - or any way of moral reasoning - is as important in understanding moral behaviour as is the content of the beliefs themselves. The moral fibre and value systems of our people are constituted and reconstituted in our schools, in our places of worship, on the sports fields and in the workplace. Many other institutions and factors will influence and shape the development of our value systems, but all will agree that our schools, colleges, learning centres and institutions of higher learning have an extremely important role to play in supporting the development of our value system and in establishing the regeneration of the ethical fibre of our society.

There is a long and very rich tradition of viewing democracy and education as inseparable: democracy as a basic value and practice in education, and education as a means to strengthen and sustain democracy. Democracy was a central theme for major educational thinkers of the last century, such as John Dewey, Paulo Freire and Loris Malaguzzi. In terms of the development of thinking about education for democracy in the twentieth century, it is the figure of John Dewey that towers above all. For education to be successful as an agent of social change, among other things, it must include a focus on democratic education, solution-focused critical pedagogy, popular and community-based education and multicultural education. At classroom level, the shift challenges teachers to be accountable for the change that takes place in students. This stems from the assumption that their words and actions trigger positive behavioural and attitudinal changes in learners. Nevertheless, the teachers' task as change agents is not limited to the school setting and their students. In the disadvantaged communities, where the literacy rate is low and people are unaware of their rights and responsibilities and lack knowledge of good health habits, local teachers can also act as change agents. From a critical pedagogy perspective, teachers as cultural workers can cause change to take place in the community settings.

Democracy and teaching values education should not be perceived as separate concepts - schools can influence social change; therefore democracy and teaching have a dialogic relationship. This article holds that teaching values education has a great potential to improve and refine the practice of democracy. Values education should be derived from democratic principles, for example when teaching about justice, the school must set the example by not discriminating on 
the basis of irrelevant differences such as colour, race, creed or gender (Nieuwenhuis, 2007:17). Democracy may be reinforced by encouraging democratic attitudes in primary education; certain values need to be commonly practised within the community of early childhood institutions. This notion is supported by Dewey (2001:341), who points out that democracy involves freedom and voluntary choice, which brings together the individual and society. In line with this, values education, as a tool for social change, becomes a valuable tool for helping to bring about democratic values and behaviours. In the South African context, the democratisation of schools, among other things, is aimed at fostering a democratic culture in wider society.

Against this background, teaching values education has a role in curbing corruption and fighting poverty. As Riley (1998:132) pointed out, historical evidence shows that attempts to curb corruption are about as old as corruption itself. However, this article acknowledges the following: (1) increasing civil service wages will reduce corruption; (2) there is an emphasis on principal-agent models (incentive theory) and models of multiple corruption equilibria; (3) the World Bank has developed the broadest and most elaborate set of policies aimed at reducing corruption; and (4) the policy debate on anti-corruption strategies has at its roots the principal-agent theory of corruption. The implication is that unsatisfactory wages induce corrupt behaviour and that the latter would, therefore, diminish or disappear altogether if incomes were to rise (Andvig et al, 2000).

Although formal education institutions have a role in social reproduction, a plethora of literature on corruption underscores the importance of formal education institutions in fighting and reducing corruption and poverty. Therefore, if South Africa is serious about fighting poverty and reducing inequality, teaching values education should become a policy strategy before even considering international measures. In particular, this article regards corruption as a moral crisis and argues that fighting corruption through wage incentives alone could be extremely costly to the authorities, and would most likely have only a limited impact, unless combined with other measures. Central to this article is the assumption that values education instruction and practice, as "policy instruments", are essential for advancing democracy, improved governance and social transformation. Hence, one possible explanation is that teaching values education offers a theoretical framework for living and practising democratic values. As a policy instrument, the teaching of values education has the prospects of producing morally and ethically informed choices and decisions. At the same time, it informs and guides the implementation of anti-corruption strategies.

\section{Corruption as an obstacle to the achievement of the Millennium Development Goals (MDGs) and Education For All (EFA)}

Corruption is the single greatest obstacle to economic and social policies around the world. It is a worldwide predicament and no country is totally free of its menacing grip. In this section I wish to show that corruption is an obstacle to implementing global policies. The question arises: Is a country poor because of corruption, or is a country corrupt because of poverty? With this question in mind, the ramifications of corruption have many dimensions related to political, economic, social and environmental effects. It is widely accepted that corruption impedes democracy and the rule of law. For example, in democratic systems, public institutions and offices may lose their legitimacy when they misuse their power for private interest (Transparency Ethiopia, 2012). On the other hand, corruption results in negative consequences, such as encouraging cynicism and reducing interest in political participation; political instability; reducing political competition; undermining the transparency of political decision making; distorting political development; and sustaining political activity based on patronage, clientelism and money, etc.

Within the economic dimension, corruption leads to the depletion of national wealth (Transparency Ethiopia, 2012). Transparency Ethiopia (2012) states that corruption is often responsible for increased costs of goods and services; the funnelling of scarce public resources to uneconomical high-profile projects at the expense of much-needed projects such as schools, hospitals and roads, or the supply of potable water; diversion and misallocation of resources; conversion of public wealth to private and personal property; inflation; unbalanced economic development; a weakening work ethic and professionalism; hindrance of the development of fair trade in market structures and unhealthy competition that actually deters competition. Large-scale corruption hurts the economy and impoverishes the entire population. Within the social dimension, corruption discourages people from working together for the common good. Frustration and general apathy among the public result in a weak civil society (Transparency Ethiopia, 2012). Demanding and paying bribes becomes customary. Corruption also results in social inequality and a widening gap between the rich and the poor; civil strive; increased poverty and a lack of basic needs such as food, water and medicine; and jealousy, hatred and insecurity. According to Transparency International's 2011 Corruption Perceptions Index, corruption continues to plague too many countries around the world. The latter shows some governments failing to protect citizens from corruption, be it from 
abuse of public resources, bribery or secretive decision making. According to Transparency International's $2011 \mathrm{CPI}$ report, $80 \%$ of humans live under a corrupt government.

Closer to home, corruption is said to have been a factor in the poor service delivery in government departments, local government and the private sector. Corruption can be viewed as a primary obstacle to social and economic growth in developing countries. Hence, patronage, bribery, graft, extortion, influence padding, embezzlement and nepotism will affect the implementation of the MDGs and EFA policies. Far from being a "victimless crime", corruption is a typical symptom of moral decay and provides an extremely fertile ground for global policy failure (specifically the MDGs and EFA).

\section{Conclusion}

To summarise, notwithstanding the enormous strides and significant progress made by the South African government in bridging poverty gaps and increasing the access of social grants, corruption remains a crisis in both private and public sectors. Corruption has ramifications for economic development and affects the poor negatively. In addition, corruption may distort the composition of government expenditure, lower the quality of infrastructure and public services and lead to adverse budgetary consequences. Hence, the task of teaching values education as a mechanism to fight and reducing corruption and inequality should be seen as a long-term challenge. Corruption plays a pivotal role in the cycle of poverty, and efforts to fight and reduce corruption must be informed by an understanding of the factors that contribute to corruption. Thus policymakers need to rethink teaching values education as a strategy to fight poverty and reduce corruption and inequality.

\section{References}

Andvig, J., Fjeldstad, O. \& Amundsen, I. (2000). Research on Corruption: A Policy Oriented

Survey. Chr. Michelsen Institute (CMI) \& Norwegian Institute of International Affairs (NUPI).

Aspin, D.N. (2007). The Ontology of Values Education. In Aspin, DN \& Chapman, JD (eds).

Values Education and Lifelong Learning: Principles, Policies, Programmes. Dordrecht: Springer.

Bagnall, R.G. (2007). The Ethics of Lifelong Learning and its Implications for Values Education.

In Aspin, D.N. \& Chapman, J.D. (eds). Values Education and Lifelong Learning: Principles, Policies, Programmes. Dordrecht: Springer. Bourdieu, P. (1990). The Logic of Practice. California: Stanford University Press.

Bourdieu, P. (1988). Homo Academicus. California: Stanford University Press.

Bourdieu, P. (1984). Distinction: A Social Critique of the Judgement of Taste. Cambridge, MA: Harvard University Press.

Bourdieu, P. \& Passeron, J.C. (1990). Reproduction in Education, Society and Culture. London: Sage.

Collins, R. (1990). Homo Academicus by Bourdieu. American Journal of Sociology, 460-463.

Dewey, J. (1964). John Dewey on Education: Selected Writings. New York: Modern Library.

Dewey, J. (1946). Philosophy of Education. Paterson, NJ: Littlefield Press.

Edwards, E. (1951). Education as a Social Instrument. The School Review, 59(7), 394-402.

Harris-White, B. \& White, G. (eds) 1996. Liberalization and the New Corruption. IDS Bulletin, 27(2).

Heidenheimer, A.J., Johnston, M. \& LeVine, V.T. (1989). Political Corruption. A Handbook. New Brunswick: Transaction Publishers.

Goldsmith, A. (1999). Slapping the Grasping Hand: Correlates of Political Corruption in Emerging Markets. American Journal of Economics and Sociology, 58(4), 866-883.

Johnson, J.A., Musial, D., Hall, G.E., Gollnick, D.M. \& Dupuis, V. (2008). Foundations of American Education: Perspectives on Education in a Changing World. Boston: Pearson Educational.

Kidder, R.M. (2009). How Good People Make Tough Choices: Resolving the Dilemma of Ethical Living. New York: Harper Collins.

Mauro, P. (1997). Why Worry About Corruption? Washington, D.C.: International Monetary Fund.

Nieuwenhuis, J. (2007). Growing Human Rights and Values in Education. Pretoria: Van Schaik.

Nash, R. (1990). Bourdieu on Education and Social and Cultural Reproduction. British Journal of Sociology of Education, 119(4), 431447 .

Ochulor, C.L. \& Bassey, E.P. (2010). Analysis of Corruption from the Ethical and Moral Perspectives. European Journal of Scientific Research, 44(3), 466-476.

Paldam, M. (1999). The Big Pattern of Corruption: Economics, Culture and the Seesaw Dynamics. Working Paper No. 1999-11, Department of Economics, University of Aarhus.

Pendlebury, S. \& Enslin, P. (2007). What Kinds of People Are We? Values Education After Apartheid. In Aspin, DN \& Chapman, JD (eds). Values Education and Lifelong Learning: Principles, Policies, Programmes. Dordrecht: Springer.

Priestley, M. (2011). Schools, Teachers, and Curriculum Change: A Balancing Act? Journal of Education Change, 12, 1-23.

Rijckeghem, C. \& Weder, B. (1997). Corruption and the Rate of Temptation: Do Low Wages in the Civil Service Cause Corruption? Working Paper WP 97/73, International Monetary Fund, Washington D.C. 
Riley, S.R. (1998). The Political-Economy of Anti-Corruption Strategies in Africa. TheEuropean Journal of Development Research, 10 (June), 129-159.

Stambach, A. (2012). Rethinking Culture and Education. British Journal of Sociology of Education, 33(2), 323-333.

Stewart, J.S. (1975). The School as a Just Community: Transactional Development Moral Education. In Meyer, J, Burnham, B \& Cholvat, J (eds). Values Education: Theory/Practice/Problems/Prospects. Ontario. Wilfrid Laurier University Press. Transparency Ethiopia (2012). What are the effects of corruption?

http://transparencyethiopia.org/index.php?option=com content\&view=article\&id=17\%3Awhat-are-the-effects-ofcorruption\&catid=7\%3Afaq\&ltemid=7\&lang=en (accessed on 2012/07/25).

Treisman, D. (2000). The Causes of Corruption: A Cross National Study. Journal of Public Economics, 76, 399-457.

Tzanakis, M. (2011). Bourdieu's Social Reproduction Thesis and the Role of Cultural Capital in Educational Attainment: A Critical Review of Key Empirical Studies. Educate, 11(1), 76-90.

Uslaner, E. (2007). Corruption and the Inequality Trap in Africa. Afro Barometer Working Paper No. 69, April.

Willis, P. (1981). Cultural Production is Different from Cultural Reproduction is Different from Social Reproduction is Different from Reproduction. Interchange, 12(2-3), 48-67. 
